\section{UNIVERSITY \\ of DEBRECEN \\ FACULTY OF \\ HEALTH}

NYÍREGYHÁZA

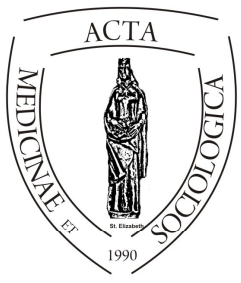

ACTA

MedSoc

VOLUME 5.

2014

\title{
Segélyezés és támogató rendszerek
}

\author{
Balogh Erzsébet - R. Fedor Anita \\ Debreceni Egyetem, Egészségügyi Kar, \\ Szociális és Társadalomtudományi Intézet
}

\begin{abstract}
The aim of our study in case of panels research to assess natural and artificial support systems, social services and the development of information, views and opinions between 2008-2012.

Before analyzing the towns data let us see some information about costs of social protection and goverment aid. It was determined that the cost of social protection shows a decreasing trend in the European Union in the GDP \%. Within this costs of aid that is only given by goverments are on a very low level in the expenditure side of government finances. We also examined the exist of support systems and we showed not only these systems but also the types of problems that citizens ask for help. Our results show that citizens are more hopeful in case of getting help from support systems in 2010 than they were in the year before.

Later we gathered information about direct government aid. We examined which are those types of aid that can help the citizens to solve their problem and what they think about the efficiencies of them, from where they get information about different kinds of aids, what can be the reasons that they do not get any aid. We also would like to know how the citizens of Nyíregyháza would change the conditions of eligibility for aid. Our results show that, in the year of our study, citizens prefer cash benefits even though they feel less and less effective the assistance of means-tested benefits, which can indicate the increasingly deepening poverty in the city. The proportion of people receiving aid was significantly reduced in 2012 that is due to public employment programs as well.
\end{abstract}

Keywords: social protection, social benefits, natural, artificial supporting systems, social support

DOI: $10.19055 / \mathrm{ams} .2014 .5 / 12-13 / 6$ 


\section{Bevezetés}

Megbízható források, hiteles statisztikai mérőszámokkal mérhető adatok nincsenek ma Magyarországon arra vonatkozóan, hogy mennyi a segélyezett háztartások száma. A szociális szakmabeliek, kutatók és az éppen aktuálisan hatalmon lévők között mindig is vita tárgyát képezi a jóléti közkiadások csökkentésének jogosultsága. A jóléti kiadások csökkentésének csupán az a hatása mérhető fel, hogy hogyan jelenik ez meg költségvetési kiadás csökkentés oldaláról, társadalmi hatásai mérhetetlenek (Tausz 2010).

Tanulmányunk első részében felvillantjuk a szociális védelemre fordított kiadások GDP \%-ban való alakulását az Európai Unióban és Magyarországon, helyzetképet adunk a kifejezetten önkormányzati szociális segélyezési kiadások államháztartási kiadási oldalán való megjelenéséröl.

Az állam funkciója a közjó, a közérdek, a közfelelösség fogalmai köré csoportosítható feladatoknak az ellátása. Úgyis fogalmazhatunk, hogy az állami szociálpolitika egy olyan rendszer, amelynek célja a társadalmi integráció fenntartása, erősítése nem piaci eszközökkel. Vagyis a jóléti államnak azt a társadalmi funkcióját határozza meg, amely társadalmi célokat fejez ki egy társadalom (közösség) értékrendszerén keresztül. Külső feltételeit a társadalmi, demográfiai, ideológiai, gazdasági feltételrendszer szabályozza és alakítja, amelyeket a történelmi hagyományok erősen befolyásolnak, meghatároznak. Ebben a mezőben formálódik a szociálpolitika, amely maga is alakító ágens az intézményrendszerén keresztül. Ezen jóléti intézményrendszer pedig nem független a történelmi hagyományoktól, a társadalomtól, egy értékekkel, ideológiákkal átitatott struktúra (Mózer 2011). De hogyan is alakult hazánkban a szociálpolitika?

Az 1989-es magyarországi rendszerváltást követően elkülönült társadalmi alrendszerré, ágazattá vált a szociálpolitika a demokrácia intézményrendszerének kiépülésével. A szociálpolitikát úgy kellett kialakítani, hogy az jól illeszkedjen a megváltozott társadalmi-gazdasági körülményekhez, valamint a nemzetközi folyamatokhoz is. Már ekkor jól láthatóvá vált, hogy a szegénység megelőzésére, illetve kezelésére nagy figyelmet kell fordítani. Szükségessé vált a szociális támogatások átfogó, új szabályozása. Ezen a területen a két legfontosabb intézkedés az „1993. évi III. törvény a szociális igazgatásról és ellátásokról”, valamint az „1997. évi XXXI. törvény a gyermekek védelméről és a gyámügyi igazgatásról" megalkotása és elfogadása volt. Mindkét törvény a szubszidiaritás elvére alapoz, vagyis arra, hogy a közösség feladata a szociális biztonság megteremtése, a helyi önkormányzatok feladata a pénzbeli és természetbeni ellátások biztosítása, a különböző szociális alapszolgáltatások és szociális szakosított ellátások, valamint a gyermekvédelmi szolgáltatások kialakítása és müködtetése (Tausz 2010). 
2013. január 1-jéig az ellátásokkal kapcsolatos alapvető feladat- és hatáskörök a települési önkormányzatokat illették meg, hiszen a szubszidiaritás elvének értelmében ezen a szinten ismerik legmélyebben, legjobban a helyi szükségleteket, helyi sajátosságokat, az életkörülményeket. Éppen ezért külön kitérünk az önkormányzati segélyezésre.

Tanulmányunk utolsó részében a nyíregyházi háztartáspanel adatokkal dolgoztunk a 2008-2012-es évek elemzésével. Megvizsgáltuk, hogy melyek azok a segélyezési típusok amelyek segítséget nyújthatnak a városlakóknak problémáik megoldásában, illetve hogy hogyan vélekednek az azokat igénylök azok hatékonyságáról, honnan szerzik értesüléseiket a különböző segélytípusokról, mik lehetnek azok az okok amelyek miatt nem részesülnek támogatásban, továbbá kíváncsiak voltunk arra, hogy hogyan alakítanák át a nyíregyháziak a segélyezésre való jogosultság feltételeit.

\section{A segélyezési kiadásokról általában}

Kuivalainen (2005) megfogalmazásában a segély adókból finanszírozott szociális transzferjövedelem, amelyet rászorultaknak juttatnak különböző jövedelem és vagyon vizsgálatán keresztül. A segélyezés pedig része a társadalmi biztonsági rendszernek. A szegénység enyhítését szolgálja azok számára, akik a piaci jövedelmekből nem tudják szükségleteiket kielégíteni, és akiknek nem tudnak megélhetést biztosító minimális jövedelmet juttatni a jóléti rendszer egyéb intézményei. Vagyis, a segélyezés a szegénység megelőzésére nem alkalmas, csupán a szegénység enyhítését szolgálja, főleg a mélyszegénységben élő családok esetén. A meghatározás értelmében a segély adókból finanszírozott jövedelem, így az államnak nagy szerepe van bevételeinek újraelosztásában. Az 1. táblázatban jól láthatjuk a szociális védelmi kiadások ${ }^{1}$ alakulását 2007-2011 közötti időszakra vonatkozóan.

\footnotetext{
${ }^{1}$ A szociális védelem alá eső kockázatok/szükségletek az EU konvenció szerint: öregség, betegség/egészséggondozás, rokkantság, hátrahagyottak, család/gyermek, munkanélküliség, lakás, máshová nem sorolt egyéb kirekesztettség.
} 


\begin{tabular}{|c|c|c|c|c|c|}
\cline { 2 - 5 } \multicolumn{1}{c|}{} & 2007 & 2008 & 2009 & 2010 & 2011 \\
\hline EU 27 & 26,1 & 26,8 & 29,6 & 29,3 & 29 \\
\hline Magyarország & 22,7 & 22,9 & 24,3 & 23,1 & 23 \\
\hline
\end{tabular}

1.táblázat. ${ }^{2}$ Szociális védelemre fordított összes kiadás a GDP százalékában. Forrás: Eurostat, Social protection statistics, 2013.

http://epp.eurostat.ec.europa.eu/statistics_explained/index.php/Social_protection_statistics

A táblázatból jól látható, hogy 2009-től kezdődően a szociális védelemre fordított kiadások visszaszorulása jellemző. A pénzügyi és gazdasági válság tovább súlyosbította a rászorultak helyzetét, helyzetük javulásának kézzelfogható eredményei nem látszanak, ami egyébként azt is valószínüsíti, hogy a válság Európában sok helyen - így Magyarországon is - a legszegényebbeket sújtotta. Mindazon veszély megléte mellett, hogy a kiadások csökkentésével a tagállamokban a szociális védelmi rendszerek csökkentették, vagy éppen semlegesítették a gazdasági stabilizációs szerepet, ami hozzájárulhat a recesszió súlyosbodásához.

A magyarországi helyzetet közelebbröl megvizsgálva és kifejezetten az önkormányzati segélyezést alapul véve a 2 . táblázat foglalja össze a kiadások alakulását.

\begin{tabular}{|c|c|c|}
\hline \multirow{2}{*}{ Év } & \multicolumn{2}{|c|}{ Felhasznált összeg } \\
\cline { 2 - 3 } & Összesen, milliárd forint & a GDP százalékában \\
\hline 2008 & 130,4 & 0,49 \\
\hline 2009 & 137,8 & 0,54 \\
\hline 2010 & 141,9 & 0,53 \\
\hline 2011 & 152,2 & 0,55 \\
\hline
\end{tabular}

2.táblázat. ${ }^{3}$ Az önkormányzati segélyezésre felhasznált összeg alakulása.

Forrás: Társadalmi helyzetkép - 10. fejezet Szociális védelem, 2010:12;

Jövedelempótló támogatások az önkormányzati segélyezésben, 2000-2011:4

A táblázat adataiból jól látható, hogy Magyarországon évek óta a GDP 0,5\%-a körüli összegben fordít az állam önkormányzati segélyezésre, ami kifejezetten jelentéktelen tételnek tünik a kiadási oldalon. De akármennyire is alacsonyak ezek a számok mégis fontos szerepet töltenek azok be a szegény családok életé-

\footnotetext{
2 2012-es adatok nem állnak rendelkezésünkre.

${ }^{3}$ 2012-es adatok nem állnak rendelkezésünkre.
} 
ben. Annyi azonban mégis érzékelhető, ha csak csekély mértében is, de évrőlévre magasabb az önkormányzati segélyezésre felhasznált kiadások alakulása, ami jelezheti az önkormányzatokhoz fordulók emelkedett számát. Saját kutatásunk kitér ennek vizsgálatára is.

\section{Támogató rendszerek}

A természetes támogatórendszerek feltárását elsőként annak vizsgálatával kezdtük, hogy a megkérdezettek kinek a segítségére számíthatnak szociális problémáik megoldásában ${ }^{4}$. Az eredményeket az 1. ábra szemlélteti.

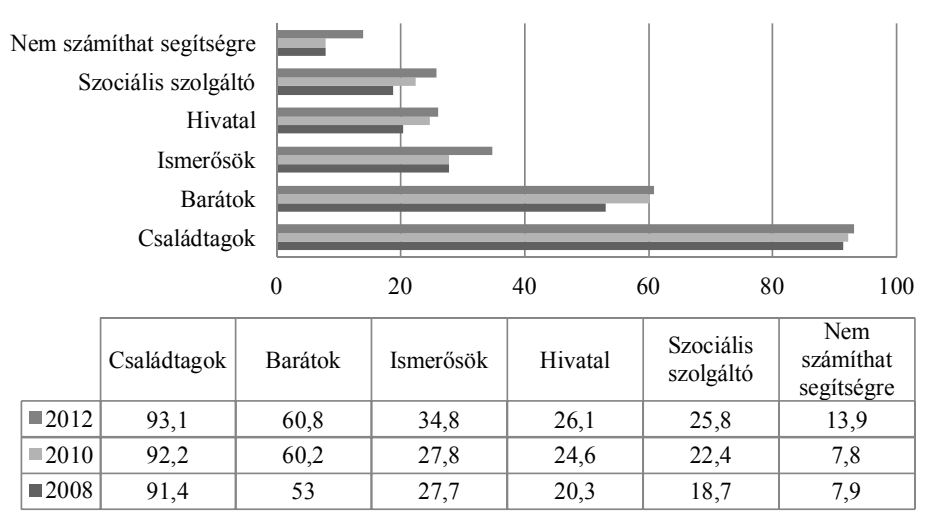

1. ábra. Problémainak megoldásában kire számíthat? az „Igen” válaszok arányai a városban, 2008-2012 (\%) Forrás: Háztartáspanel 2008, 2010, 2012.

Az adatok azt mutatják, hogy 2012-ben az előző vizsgálati évekhez képest a városlakók bizakodóbbak a támogató rendszerek segítségnyújtásában. Leginkább a családra, mint természetes támogató rendszerre számíthatnak segítségre a városlakók problémájuk megoldása érdekében, majd a barátokra, ismerősökre. Öket követik a mesterséges támogató rendszerek, mint a Polgármesteri Hivatal és a szociális szolgáltató. (Lásd erről bővebben Balogh-Fábián (2012) korábbi

\footnotetext{
${ }^{4}$ A városlakók társas kapcsolatainak, családi, rokoni kapcsolatainak alakulásáról lásd bővebben Huszti (2012) tanulmányát, valamint a jelen kötetbeli írását.
} 
tanulmányát). Ezek tekintetében tovább nőtt a bizalom a vizsgálatban résztvevők körében, ami azt mutatja, hogy nő az emberek reménye arra vonatkozóan, hogy ezek a rendszerek segítségükre lesznek problémájuk megoldásában. Egy városkörzetre vonatkozóan még inkább ezt mutatják az eredmények, melyet a 2 . ábrán mutatunk be. Tovább nőtt a városban azok aránya, akik úgy érzik, hogy senkitől nem számíthatnak segítségre, amely hátterében az egyre mélyülő szegénység ${ }^{5}$ és az ezzel járó egyre súlyosabbá váló problémák állhatnak.

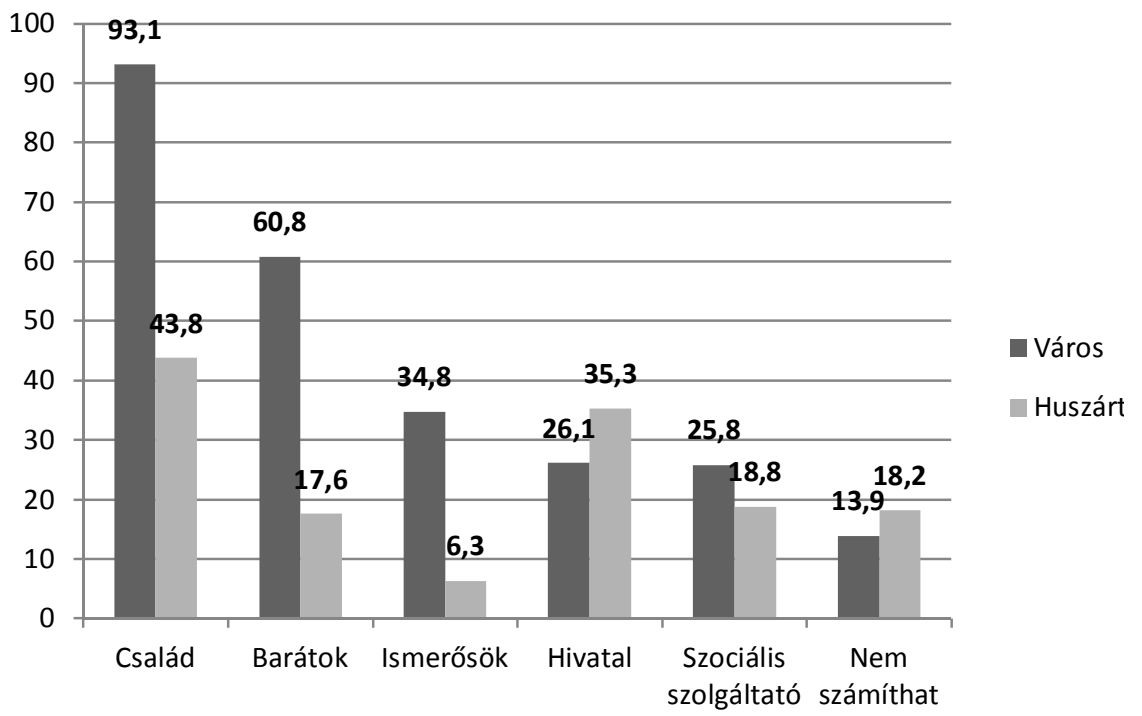

2. ábra. Problémainak megoldásában kire számíthat?

-az „Igen” válaszok arányai a városban és a Huszár telepen ${ }^{6} 2012(\%)$.

Forrás: Háztartáspanel 2012.

A Huszár lakótelepen élök a városlakókhoz viszonyítottan sokkal kevésbé fordulnak problémák esetén a természetes támogató rendszerükhöz, ők jobban bíznak, jobban számíthatnak a mesterséges támogató rendszerek segítségnyújtásában, amely valószínüsíthetően sajátos élethelyzetükböl, életkörülményeikből adódhat. (Lásd erről bővebben: Filepné Nagy É - Fónai M - Fábián G: A Sza-

\footnotetext{
${ }^{5}$ A városlakók jövedelmi helyzetére vonatkozó adatokat bővebben lásd Fábián - Takács (2012) tanulmányát, illetve a szerzők jelen kötetben található tanulmányát.

${ }^{6}$ A Huszár telep a város legnagyobb szegregátuma. Jellemzően sok gyerekes, munkanélküli, rendszeres jövedelem nélküli családok lakják.
} 
bolcs - Szatmár - Bereg megyei népesség szociális helyzete és egészségi állapota. In: Fónai M - Pénzes M - Vitál A (szerk.): Etnikai szegénység, etnikai egészségi állapot? A cigány népesség élethelyzete és kitörési lehetőségei ÉszakkeletMagyarországon. Nyíregyháza: Krúdy Könyvkiadó - Szocio East Egyesület, 2006. 43-75.). Szuhay (1999) mutat arra rá, hogy rokoni, testvéri köteléken alapulnak, illetve müködnek a roma közösségek, a baráti kapcsolatok pedig éppen ezen szoros kötelékek kizárólagossága miatt hiányosak. Kissé ellentmond ennek Albert és kutatótársa (2006) vizsgálata, hiszen ők ezen célcsoport vizsgálatánál viszonylag magas arányban mutatták ki a nem roma barátok említését. A fogalmak értelmezésében rejlő eltérések adhatják a magyarázatot ezekre az eltérő eredményekre. Vizsgálatunkhoz hasonló eredményeket mutat Fónai (2011) kutatása. Adatai azt mutatják, hogy a roma lakosság problémái megoldásában a Polgármesteri Hivatal szerepe a legjelentősebb. Magyarázata lehet ennek a patrónus - kliens viszony, mely Angelusz - Tardos (2006) szerint nem csupán a premodern társadalmak sajátja, hanem a fejlett demokráciák viszonyai közt is megtalálható, igaz ugyan, hogy társadalmi szféraként eltérő, más-más hangsúlylyal. Ezt erősítik tovább a következő ábrán bemutatott eredmények.

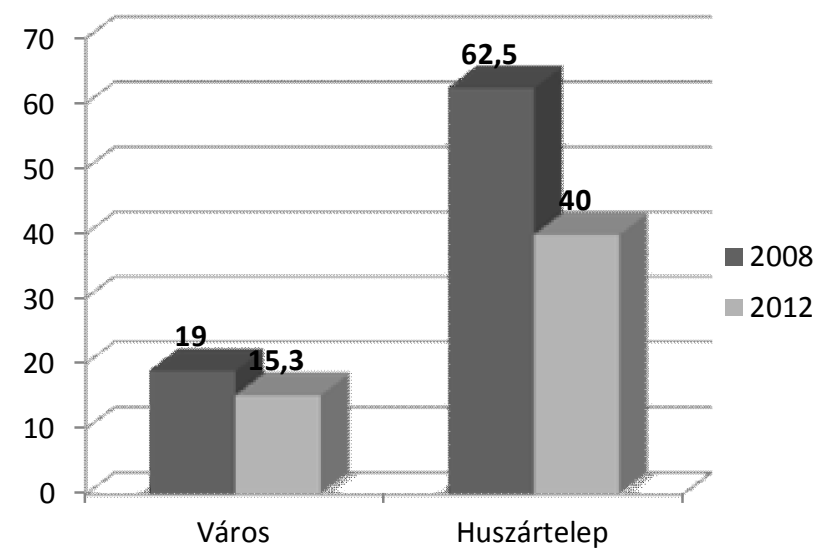

3. ábra. Fordult-e már problémájának megoldása érdekében a Szociális Osztályhoz? 2008, $2012(\%)$

Forrás: Háztartáspanel 2008, 2012

A 3. ábrán jól láthatjuk, hogy jelentős az eltérés a szociális osztályhoz fordulók vonatkozásában. Több mint háromszoros a városon belül az osztályhoz segítségért folyamodók aránya a Huszár telepen élők esetében. Ök leginkább anyagi 
okok miatt, lakástámogatási, gyermekvédelmi támogatás, gyógyszer támogatási és tüzifa támogatási kérelmek ügyében kérnek segítséget.

\section{Önkormányzati segélyezés}

A segélyezési rendszer alapjait az 1993. évi III. törvény a szociális igazgatásról és ellátásról, valamint az 1997. évi XXXI. törvény a gyermekek védelméről és a gyámügyi igazgatásról rakta le. A szociális törvényben elsősorban a felnőtt korúak pénzbeli és természetbeni ellátásai kerültek szabályozásra, a gyermekvédelmi törvény a gyermekek segélyezését reformálta meg.

A segélyek funkciója alapján három nagy csoport különíthető el (Ferge 1995, 1996a, 1996b, 1998, Darvas és Mózer 2004, Mózer 2004). Ezek a következők:

- jövedelempótló támogatások

- kötött felhasználású (kiadást kompenzáló) segélyek, amelyek a helyi rendeletalkotás körébe vannak utalva,

- átmeneti segélyek, amelyek a helyi rendeletalkotás körébe tartoznak.

A jövedelempótló támogatások körében az ellátások a jövedelem alacsony szintjét, a jövedelem hiányát pótolják, kompenzálják. Ide tartoznak az aktív korúak ellátásai az időskorúak járadéka és az ápolási dij. Az önkormányzatok mozgástere minimális, hiszen a jogosultsági feltételeket a törvényi szabályozás egyértelmüen meghatározza. Havi rendszerességgel folyósított, hosszabb időtartamú ellátások. Pénz formájában nyújtott, szabad felhasználású támogatások. Finanszírozásuknál meghatározó a központi költségvetésböl történő finanszírozás (Ferge 1995, 1996a, 1996b, 1998, Darvas és Mózer 2004, Mózer 2004)..

A következő csoportot a kiadáskompenzáló, vagy kötött felhasználású segélyek alkotják (Ferge 1995, 1996a, 1996b, 1998, Darvas és Mózer 2004, Mózer 2004). A jövedelemigazoláshoz kötött, jövedelemkiegészítő támogatások tartoznak ide. Ezen segélyek valamilyen speciális helyzetre reagálnak. Ezeknél a segélyeknél általában magasabb a jövedelemküszöb, mint a jövedelempótló támogatásoknál. A szociális törvény a lakhatáshoz, az egészséghez és az eltemettetéshez való jogot ismeri el, mint alapszükségletet. A három alapszükséglethez köthető ellátás a lakásfenntartási támogatás, a közgyógyellátás és a temetési segély, de ide tartozik a gyermekvédelmi törvényben szabályozott rendszeres gyermekvédelmi támogatás is, mint a gyermekneveléshez való hozzájárulás.

A harmadik csoportot az átmeneti - eseti - segélyek alkotják (Ferge 1995, 1996a, 1996b, 1998, Darvas és Mózer 2004, Mózer 2004). Ezek esetében a legáltalánosabb a szabályozás. A jogszabály az időszakos létfenntartási gondokat, a létfenntartást veszélyeztető élethelyzetet nevesíti a jogosultság feltételénél, meghatározásánál. Itt van a legnagyobb mozgástere az önkormányzatoknak a helyi 
rendeletek megalkotásánál. Az átmeneti segélyformák a következőképpen csoportosíthatóak:

- betegséggel összefüggő segélyek,

- lakással-lakhatással összefüggő segélyek,

- időskorúakkal kapcsolatos ellátások,

- gyermekekkel kapcsolatos ellátások.

A röviden vázolt segélyezési típusoktól azért jóval bonyolultabb a magyarországi pénzbeli szociális ellátás rendszere. Gyulavári és Krémer (2006) összesen 44 féle pénzbeli szociális ellátást talált, amelynek legalapvetőbb szabályait 11 jogszabály tartalmazza. Tanulmányukban rámutatnak arra, hogy a 44 féle támogatás mellett még több tucat egyéb ellátási, támogatási módszert, kedvezményt nyújt még az állam.

Az önkormányzat által nyújtott segélyezés esetében fontos megjegyeznünk, hogy ezek az ellátások rászorultsági alapon, nem alanyi jogon járnak. A segélyezések esetében fontos szerepe van a kevésbé választhatóság elvének, azaz a segélyek összegét úgy kell megállapítani, hogy az ne érje el a mindenkori minimálbér összegét. Mindezt annak érdekében, hogy az állam által nyújtott segélyek kevésbé legyenek vonzóbbak a munkavállalásnál. Ezért az önkormányzati támogatások esetében minden esetben vizsgálják a kérelmező rászorultságát. Forrástesztet alkalmaznak, azaz vizsgálják az igénylő jövedelmi, esetenként vagyoni helyzetét. Ezt kiegészülhet egy munkateszttel, vagyis munkavégzésre kötelezéssel, de akár vizsgálhatják a kérelmező és családja érdemességét, magatartását is.

Ezen típusú támogatásoknál az ún. szelektív módszert alkalmazzák. Ilyenkor az önkormányzat a saját eljárási szabályai alapján folytatja le kiválasztási gyakorlatát. A jog ezekben az esetekben legfeljebb korlátozza az ügyintézőket a döntés tartalmi lehetőségeiben és az alkalmazható eljárásokban. Az arra vonatkozó döntést, hogy a kérelmezőnek szüksége van-e az adott ellátásra, és hogy teljesíti-e a segélyt igénylő a jogosultsági kritériumokat minden esetben az ügyintéző, az önkormányzat hozza meg. A hivatali ügyintézőnek nagyfokú szubjektív mérlegelési lehetősége van az elbírálás folyamatában, nagy a hibalehetősége még akkor is ha egyértelműek az elbírálás folyamatainak szabályai. Ezért van nagy jelentősége a szelektív módszerek alkalmazásánál, hogy mindig világosan meg legyenek állapítva az elbírálás szabályai, tisztázottak legyenek a kérelmezők feljebbviteli, panaszjogai (Krémer 2009).

A pénzbeli és természetbeni ellátásokhoz, a jóléti szolgáltatásokhoz az állam normatív módon járult hozzá. Míg a forrásokat a helyi és a központi állam megosztja, a felelősséget nem. A felelősség egyedül a helyi önkormányzatokat illeti (Mózer 2006). 


\begin{tabular}{|c|c|c|c|c|c|c|}
\hline \multirow{4}{*}{ Év } & \multirow{3}{*}{$\begin{array}{l}\text { Jövede- } \\
\text { lempótló }\end{array}$} & \multirow{3}{*}{$\begin{array}{l}\text { Kiadás- } \\
\text { csökkentö }\end{array}$} & \multicolumn{3}{|c|}{ Ebböl } & \multirow{4}{*}{ Egyéb } \\
\hline & & & $\begin{array}{c}\text { Gyermek- } \\
\text { nevelési }\end{array}$ & Lakhatási & $\begin{array}{c}\text { Egészség- } \\
\text { ügyi }\end{array}$ & \\
\hline & & & \multicolumn{3}{|c|}{ kiadást kompenzáló } & \\
\hline & \multicolumn{5}{|c|}{ támogatásokra fordított összeg nagysága } & \\
\hline 2007 & 64,7 & 29,1 & 6,1 & 17,9 & 3,7 & 6,3 \\
\hline 2008 & 68,5 & 25,4 & 6,1 & 15,4 & 2,8 & 6,1 \\
\hline 2009 & 65 & 29,1 & 10,8 & 14,8 & 2,4 & 5,9 \\
\hline 2010 & 63,9 & 29,8 & 10,8 & 15,7 & 2,1 & 6,3 \\
\hline
\end{tabular}

3. táblázat

Az önkormányzati segélyekre fordított kiadások funkció szerinti megoszlása (\%). Forrás: Társadalmi helyzetkép - 10. fejezet Szociális védelem, 2010:13.

A 3. táblázatból kitünik, hogy valamennyi vizsgált évben a jövedelempótló kiadások teszik ki az önkormányzati segélyekre fordított kiadások több mint felét. Mint már feljebb említettük ide tartoznak a hátrányos munkaerő- piaci helyzetü aktív korúak ellátásai, az időskorúak járadéka, valamint az ápolási díj. Ezen támogatásokat azon szociálisan rászoruló személyek vehetik igénybe, akiknek más módon nem biztosított a megélhetése. Annak ellenére, hogy ezeknek az ellátásoknak a szabályai nagymértékben és többször is szigorítva lettek, nem csökkentek az ellátásokat igénybevevők száma. A 3. táblázat is ezt támasztja alá, vagyis azt, hogy a szigorítások ellenére nem csökkent jelentősen a jövedelempótló segélyek fordított kiadások. A jövedelempótló támogatások kiadásaira fordított magas aránya miatt indokoltnak tartjuk ezen támogatási forma változásainak áttekintését.

Az ellátás szabályainak szigorításánál elsősorban a hátrányos munkaerő- piaci helyzetü aktív korúak önkormányzati ellátásának változásaira gondolunk. Röviden tekintsük át ezeket a változásokat a tárgyévre érvényes 1993. évi III. törvény tükrében.

A változások még 2000-ben kezdődtek meg. Ekkortól fokozatosan vezették ki a törvény rendelkezései alól a munkanélküliek jövedelempótló támogatását, melynek helyét a rendszeres szociális segély vette át. A segélyben részesülteknek 30 napnyi közmunkát is kellett végezniük, melynek célja leginkább a munkavállalási hajlandóságuk ellenőrzése, az újbóli munkába állás ösztönzése volt. 2001-ben és 2002-ben a kedvező munkanélküliségi mutatók (a ráta 6\% alatt maradt) mellett csökkent a támogatottak létszáma. Az ezt követő időszakban a 
munkanélküliség növekedésével párhuzamosan az ellátottak köre is folyamatosan bővült, egészen 2009-ig. 2009-ben kezdődött meg a rendszeres szociális segély bázisának szükítése. A segélyben részesülőket két csoportra bontották. Az egyik csoport ezután vagy rendelkezésre állási támogatásban részesült vagy közcélú munkában vett részt. A támogatottak másik csoportja (egészségkárosodottak, 55 év felettiek, 14 év alatti gyermeket nevelők, illetve a helyi rendeletben meghatározott feltételeknek megfelelő személyek) továbbra is rendszeres szociális segélyben részesült. Mindeközben lényeges változást jelentett, hogy 2006ban a segély családi támogatássá vált, azáltal, hogy mind a jogosultság, mind a segély összege - a család kiadási szerkezetéhez igazodva - az „egy fogyasztási egységre jutó havi családi jövedelemtől” függött. A rendszeres szociális segély ettől kezdve nem egyösszegü, hanem a család egy fogyasztási egységre jutó jövedelmét egészítette ki a jogszabályban meghatározott mértékig. A segély vásárlóereje ennek következtében jelentős mértékben, közel 35 százalékkal növekedett. Ebben az időben az ellátás bírálatok kereszttüzébe került. A bírálatok kiemelték, hogy a támogatás a munkavállalás ellen ösztönöz, és feszültséget kelt az alacsony bérü foglalkoztatottak és a segélyezettek között. Éppen ezért 2007 januárjától a nettó minimálbérben maximálták a támogatás összegét, ami 2010ben 60236 forint volt, de miután a segély havi összege a családi jövedelemhatár összegének és a jogosult családja havi összjövedelmének különbözete, az egy segélyezettre jutó átlagos kifizetés nem érte el a 26800 forintot. Ezzel szemben a rendelkezésre állási támogatás fix összegü lett megegyezett a mindenkori öregségi nyugdíj legkisebb összegével, vagyis 2010-ben 28500 forint volt (Társadalmi helyzetkép 2010).

Az ezt követő években az ellátási forma még szorosabban kapcsolódott a közfoglalkoztatási programokhoz. A komplex intézkedések célja elsősorban az volt, hogy a munkára képes, tartósan munkanélküli személyek fokozottabb mértékben vegyenek részt valamely közfoglalkoztatási programban, hogy rendszeres munkajövedelemhez jussanak, és közelebb kerüljenek a munka világához. Fontos megjegyezni, hogy a bérpótló juttatás bevezetésével megjelent az ellátásokra való érdemesség is, hiszen a települési önkormányzatok ettől kezdve vizsgálhatják az igénylök lakókörnyezete rendezettségének biztosítására vonatkozó, az illetékes önkormányzat helyi rendeletében megállapított feltételeket teljesítését is. 2012-ben fontos változás, hogy a jogalkotó a foglalkoztatást helyettesítő támogatás havi összegét már csak a mindenkori öregségi nyugdíj 80\%-ában határozta meg, ami 22800 forintot jelent. 


\begin{tabular}{|c|c|c|c|}
\hline & $\begin{array}{c}\text { Rendelkezésre } \\
\text { állási támogatás }\end{array}$ & $\begin{array}{c}\text { Bérpótló } \\
\text { juttatás }\end{array}$ & $\begin{array}{c}\text { Foglalkoztatást } \\
\text { helyettesítő tá- } \\
\text { mogatás }\end{array}$ \\
\hline 2010. 01. 01-jétől & 28500 forint & - & - \\
\hline 2011. 01. 01-jétől & - & 28500 forint & - \\
\hline 2011.09. 01-jétől & & - & 28500 forint \\
\hline 2012.01.01-jétől & & - & 22800 forint \\
\hline
\end{tabular}

4.táblázat

Hátrányos munkaerő- piaci helyzetű aktív korúak önkormányzati ellátásának változásai.

Forrás: Az adatok ismeretében saját szerkesztésủ ábra.

\section{Nyíregyházi segélyezési tükör}

A városlakók az országos adatokhoz hasonlóan inkább a pénzbeli ellátási formákat preferelják.

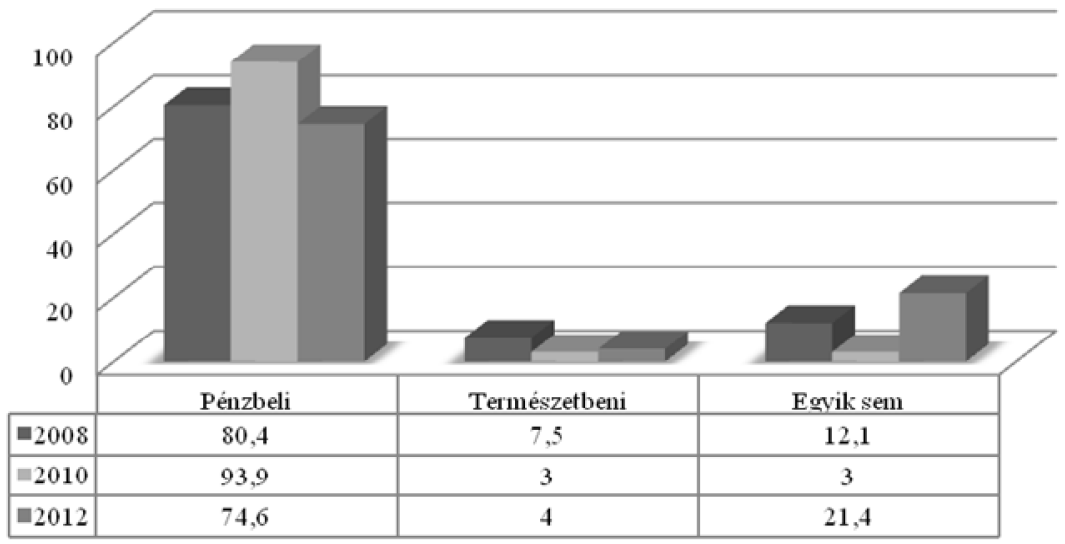

4. ábra. Milyen segélyezési forma nyújt megoldást a problémájára? (\%).

Forrás: Forrás: Háztartáspanel 2008, 2010, 2012. 
A 4. ábra jól mutatja, hogy csökkenő tendenciában, de még mindig jóval nagyobb mértékben van szüksége a városlakóknak a pénzbeli ellátásokra a természetbeni ellátásokkal szemben. Jelentősen emelkedett azok aránya, akik úgy gondolják, hogy egyik segélyezése forma sem, tehát sem a pénzbeli ellátások, sem a természetbeni ellátások nem nyújthatnak segítséget problémájuk megoldásában, amely hátterében - az előzőekben már utalt - a szegénység mélyülése állhat.

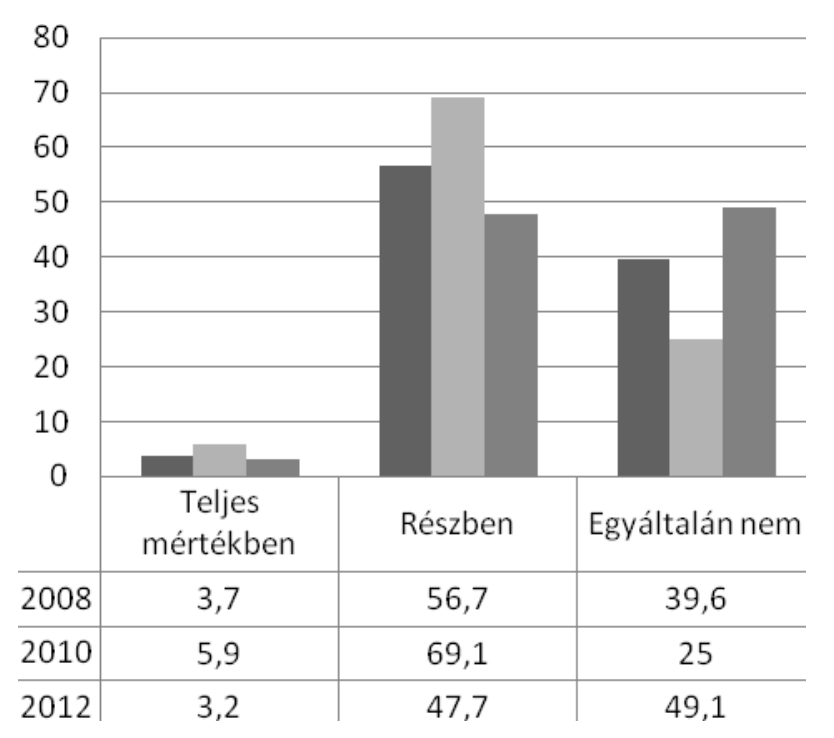

5.ábra. A megállapított segély megoldotta-e problémáját?(\%)

Forrás: Háztartáspanel 2008, 2010, 2012.

Valószínüsíthetően ugyanezen okok állhatnak az 5. ábrán megjelenő eredmények hátterében is, de összefüggést mutathat a megállapított segélyek összegével is. A megállapított segélyek inkább nem oldják meg a válaszadók problémáját. A megkérdezettek jelentős része saját bevallása szerint a problémáján minimum 50000 forint összegü, maximum 100000 forint összegü segéllyel lehetne segíteni. Ezzel szemben a megállapított segélyek összege 15-30000 forint közötti sávban mozognak 2012-ben. 
A következő ábra a segélyben részesültek arányáról nyújt információkat.

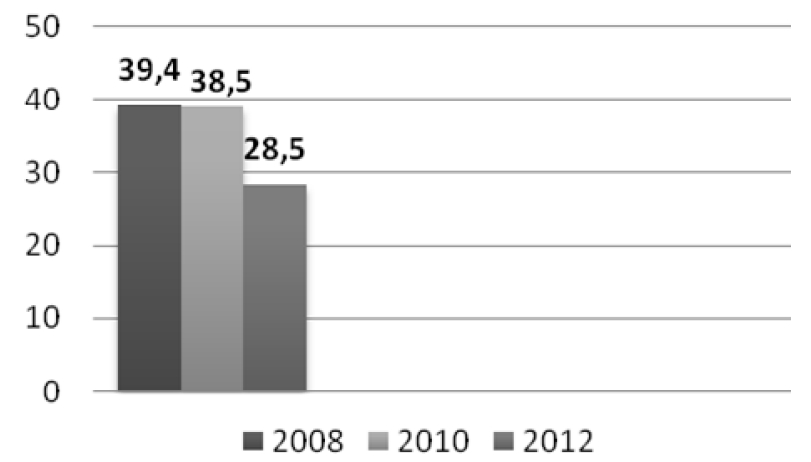

6.ábra. Az Szociális Osztályhoz fordulók körében a vizsgálatot megelőző két évben segélyben részesültek aránya (\%).

Forrás: Háztartáspanel 2008, 2010, 2012.

A 6. ábrán láthatjuk, hogy 2012-ben jelentős mértékben csökkent a városban a segélyezettek száma. Ez több okot is valószínüsíthet. Egyrészt 2012-ben érzékelhetővé váltak a városban is megváltozott jogszabályi feltételek, másrészt 2012-ben jelentősen megnövekedett a településen is a közfoglalkoztatásban részt vettek száma ${ }^{7}$. Nyíregyháza Megyei Jogú Városban is kiemelt feladat a foglalkoztatást helyettesítő támogatásban részesülők és egyéb regisztrált álláskeresők minél nagyobb számban jussanak munkajövedelemhez és kerüljenek közelebb a munka világához. Ez összhangban áll az országos adatokkal is. Tanulmányunknak nem célja a foglalkoztatási helyzet elemzése, csupán, mint egy lehetséges magyarázatként használjuk.

2012-ben legnagyobb arányban (országosan 67\%-ban) a közmunka programban vettek részt azok, akik a foglalkoztatáspolitika aktív eszközeivel támogatottak.

Ez az arány a jobb gazdasági adottságú Közép-Magyarországon (70\%) és az egyik legkedvezőtlenebb helyzetben lévő Észak-Alföldön (70\%) volt a legmagasabb. 2012-ben Magyarországon kismértékben tovább nőtt a népesség gazdasági aktivitása az előző évhez képest a lakossági munkaerő-felmérés adatai alapján. A vizsgált időszakban azért nem az általános növekedés volt a jellemző. A gazdaságilag fejlettebb régiók közül Közép-Magyarországon és Nyugat-Dunántúlon, a kevésbé fejlett térségek közül Észak- és Dél-Alföldön emelkedett leginkább a

\footnotetext{
${ }^{7}$ A város foglalkoztatási adatait lásd R. Fedor Anita (2012) tanulmányában, valamint a jelen kötetben megjelent írásában.
} 
gazdasági aktív népesség száma. 2012-ben a foglalkoztatottak számának emelkedése mellett a munkanélküliek száma is emelkedett. A munkanélküliek számának növekedése leginkább a három legfejlettebb régiót érintette. Ezzel ellentétben a három kedvezőtlenebb gazdasági helyzetü régióban (Dél-Dunántúl, Észak-Magyarország, Észak-Alföld) csökkent a munkanélküliek száma, elsősorban a közfoglalkoztatás kiszélesedésével összefüggésben. A foglalkoztatottak számának megyék szerinti változásáról megállapítható, hogy jelentős bővülést két gazdaságilag kevésbé fejlett megyében, Nógrádban és Szabolcs-SzatmárBeregben mértek (A foglalkoztatás és a munkanélküliség regionális különbségei, 2012.)

Megvizsgáltuk azokat az okokat is, amelyek miatt a kérelmező nem részesült segélyezésben. (Lásd erről bővebben Balogh- Fábián (2012) korábbi tanulmányát).

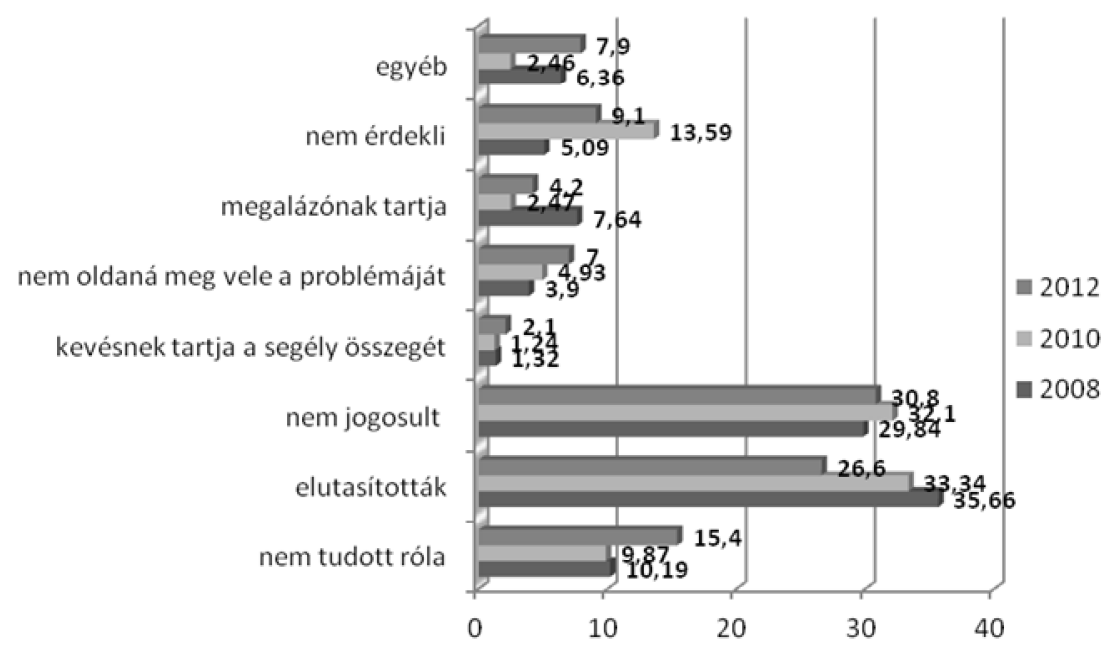

7.ábra. Ha nem részesült segélyben, annak mi az oka? 2008, 2010, 2012 (\%).

Forrás: Háztartáspanel 2008, 2010, 2012.

A 7. ábra jól mutatja, hogy a legnagyobb arányban, a vizsgálat éveiben azért nem részesültek a kérelmezők támogatásban, mert kérelmüket elutasították, vagy nem voltak jogosultak a kért ellátása. A továbbiakban kíváncsiak voltunk arra, hogy milyen okok miatt utasították el a segély iránti kérelmét azoknak, akiknek a vizsgálatokat megelőző két évben nem részesültek támogatásban. Az eredményeket a 8 . ábra tárja elénk. 


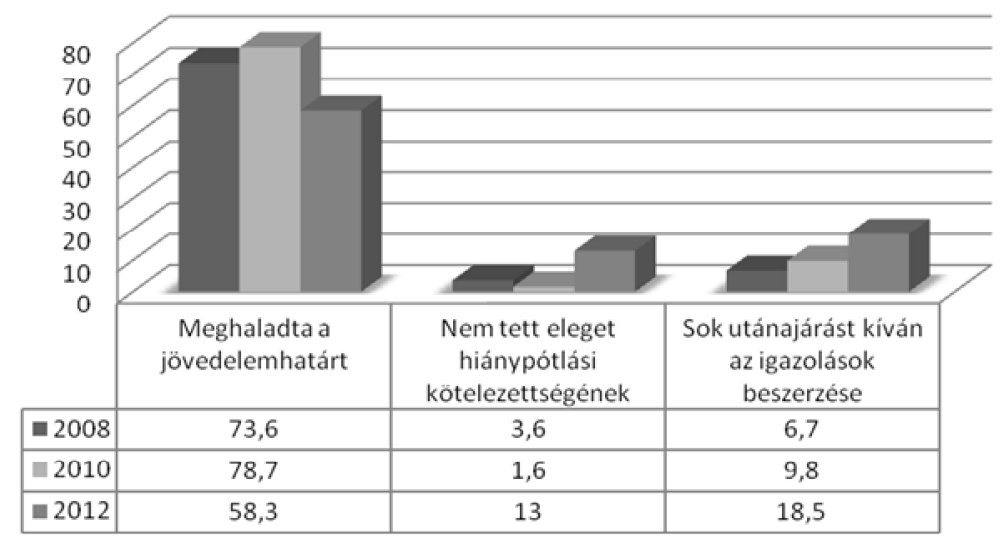

8.ábra. A segély iránti kérelem elutasításának oka, 2008, 2010, 2012 (\%). Forrás: Háztartáspanel 2008, 2010, 2012.

A segélykérelmek elutasításának döntő oka még mindig a jövedelmekben rejlik. Fontos megemlítenünk, hogy a szociális rászorultságtól függő ellátások megállapításánál a - változó mértékben - mindenkori öregségi nyugdíjminimumot veszik alapul, ami évek óta nem változott, összege 28500 forint. Jelentősen emelkedett azok aránya, akik úgy vélik, hogy sok utánajárást kíván az igazolások beszerzése, ami akár összefüggésben állhat azzal, hogy a különböző igazolások megszerzése számos költséggel járhat együtt - mint például utazási költség, illetékfizetési kötelezettség -, melyet a kérelmező nem tud megfinanszírozni. De erre még később visszatérünk.

A 7. ábra adataira visszatérve megfigyelhetjük, hogy emelkedik azoknak az aránya, akik azért nem részesülnek segélyben, mert nem tudtak róla. Ezért kitértünk annak vizsgálatára is, hogy honnan értesülnek a városlakók a segély igénybevételének lehetőségéröl. 


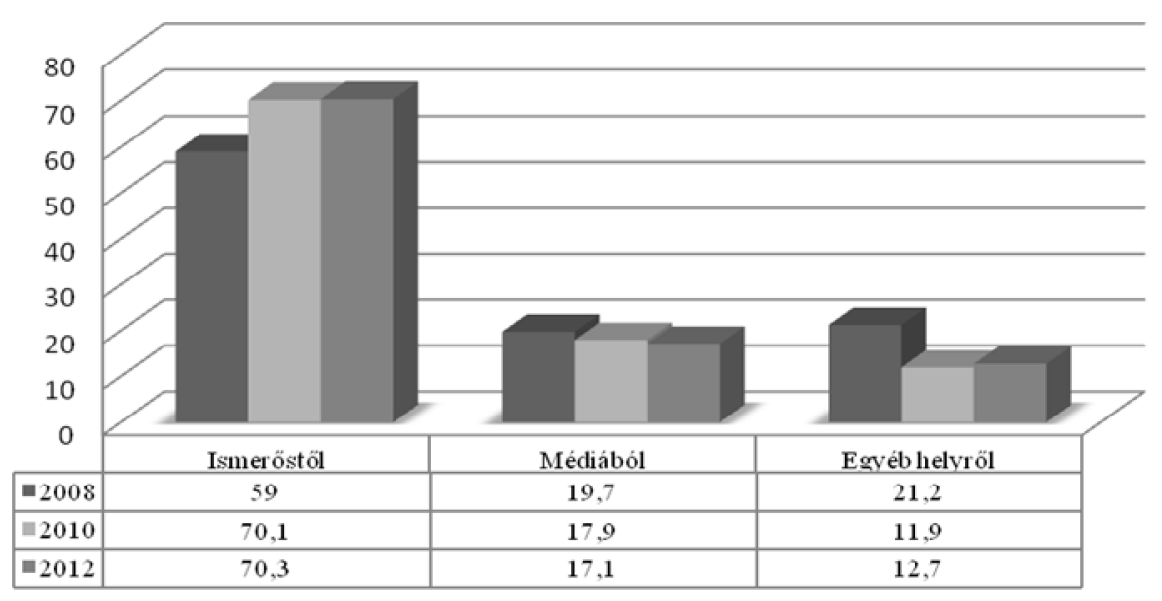

9.ábra. Honnan értesült a segély igénybevételének lehetőségéről? 2008, 2010, 2012 (\%).

Forrás: Háztartáspanel 2008, 2010, 2012.

A legtöbben még mindig az ismerőseiktől szerzik az információikat, csekély mértékben pedig csökken a médiák szerepe a városban. Az információkhoz való hozzáférés a jogbiztonság első feltétele. Azt nem tudhatjuk, hogy ez mennyire lehet könnyü a jogban és jogaikban tájékozatlan szociálisan rászorultaknak.

Neubourg et. al (2007) az igénybe nem vétel okait vizsgálta az egyének szemszögéből. Kutatásában négy lehetséges okot különböztetett meg. Ezek a juttatás összege, a folyósítás időtartama, a közigazgatási eljárás bizonytalanságát és késlekedését, az eljárással kapcsolatos információs költségeket - erre fentebb mi is utalást tettünk - és nem utolsó sorban a pszichológiai és társadalmi költségeket, ilyen például a stigmatizáció. Arra a következtetésre jutottak, hogy minél alacsonyabb a juttatás szintje és minél magasabbak a költségek, annál magasabb lesz az igénybe vételi nem arány.

Bass et. al (2005) Magyarországon az igénybe nem vétel okait vizsgálva azt állapították meg, hogy hazánkban az okok inkább társadalmi, jogi, politikai és strukturális eredetüek, mint egyéniek. „A szabályozók, a szakmapolitikai elképzelések megvalósitása, szervezeti és intézményi müködésmódok határozzák meg, hogy kik férnek hozzá az ellátásokhoz, kik tudnak élni a jogaikkal. Ez az értelmezés az egyénekkel kapcsolatban sem a problémákat, hiányosságokat keresi, hanem a társadalmi és a morális költségeket, s öket elsösorban nem áldozatnak tekinti, hanem a stigmatizáció alanyának. Ebben az értelmezésben az igénybe nem vétel annak kifejezödése, hogy az egyén nem tud élni szociális jogaival”, (Bass et. al 2005: 2). 
A családok számára egyre nagyobb terhet jelentő kiadások emelkedését sejteti a 10.ábra.

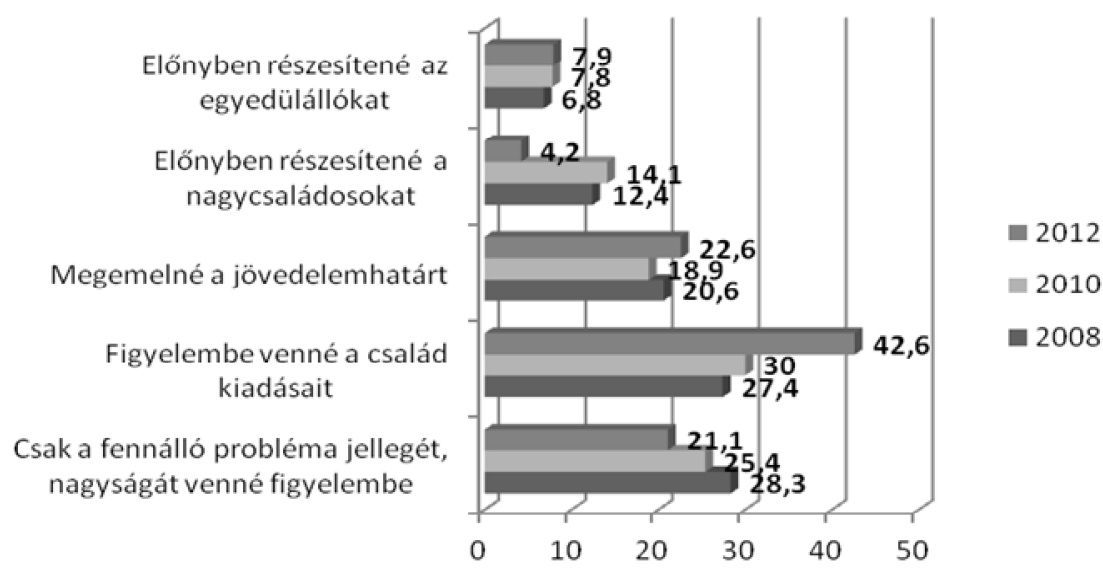

10.ábra. Hogyan változtatná meg a segélyre való jogosultság feltételeit.

Forrás: Háztartáspanel 2008, 2010, 2012.

A városban jelentősen emelkedett azok aránya, akik a segélyezésre való jogosultság feltételeinek változtatásánál kiemelt helyen kezelnék a család kiadásainak figyelembe vételét, de emelkedik azok aránya is, akik a jövedelemhatárt emelnék meg. Erőteljesen lecsökkent ezzel szemben azok aránya, akik a nagycsaládosokat részesítenék előnyben. (Lásd erről bővebben Balogh- Fábián (2012) korábbi tanulmányát).

\section{Összegzés helyett}

Minden jóléti, szociálpolitikai tevékenységnek be kell azonosítania a társadalom tagjainak azon csoportját, akiknek az életkörülményeit az adott tevékenység javítani kívánja. Ilyen értelemben a szociálpolitikai tevékenységeknek meg kell célozni az elérni kívánt célcsoportot, és olyan intézkedéseket, döntéseket kell hoznia, amelyek által a megcélzott csoporthoz valóban eljut a támogatás olyan formában, hogy az ténylegesen jobbítja, javítja a célzott személyek életkörülményeit. Értelmezésünkben a segélyezés éppen ilyen szociálpolitikai tevékenységnek számít.

A szociálpolitikai tevékenységek hatásosságát és hatékonyságát leginkább a célzottság hibáiból, tévedéseiből erednek. A célzottság hibáinak három tipikus 
esetét Krémer (2009) csoportosításában foglaljuk össze. Az első a „Holtsúly”, „Holttőke” (deadweight). Ebben az esetben a kapott segítségnek, támogatásnak semmilyen érzékelhető hatása nincs a támogatott életére. Általában a segítség túl kicsi ahhoz, hogy jobbítson az életkörülményeken. Összességükben viszont számottevő tömeget, nagyobb kiadási tételt „holtsúlyt” képeznek. A második a „Selejt”, „káló”, felesleges, elpocsékolt ráfordítás (spoilovers). Az ilyen esetekben megkapja a támogatást az is, akinek nincsen rá szüksége, a támogatásnak nincs indoka, semmi nem indokolja a közpénz költését. És végezetül az „Alacsony elérési arány", alacsony lefedettség (low take-up). Ekkor az történik meg, hogy a támogatást nem kapja meg mindenki, akinek elvileg szánták. Ez több szempontból is gondot jelent. Egyrészt egyes rászorultak ellátatlanok maradnak, másrészt nem a megfelelö, célszerü eszközökkel fogják problémáikat orvosolni, ami akár magas többletköltségeket eredményezhet.

\section{Felhasznált irodalom}

1. Albert Fruzsina - Dávid Beáta (2006): A kapcsolati tőke dimenziói etnikai metszetben. In.: Kolosi Tamás - Tóth István György - Vukovich György (szerk.). Társadalmi riport 2006. Budapest: TÁRKI 351-369.

2. Angelusz Róbert - Tardos Róbert (2006): Hálózatok a magyar társadalomban. In.: Kovách Imre (szerk.) Társadalmi metszetek. Érdekek és hatalmi viszonyok, individualizáció és egyenlőtlenségek a mai Magyarországon. Budapest: Napvilág Kiadó, 227-252.

3. Balogh Erzsébet -Fábián Gergely (2012): „Életminőség Nyíregyházán 2008-2010": Támogató rendszerek, szociális problémák és segélyezés In.: Fábián Gergely - Patyán László - Huszti Éva (szerk). Acta Mediciane et Sociologica tematikus különszáma Nyíregyháza: Debreceni Egyetem Orvos- és Egészségtudományi Centrum Egészségügyi Kar 135-155.o.

4. Bass László-Darvas Ágnes-Dögei Ilona-Ferge Zsuzsa-Juhász GáborMárton Izabella- Márton Klára-Tausz Katalin (2005): Kik és miért nem veszik igénybe a közszolgáltatásokat. Budapest: Kézirat.

5. Darvas Ágnes - Mózer Péter (2004): Kit támogassunk? Esély, 6. sz. 64-99.

6. Fábián Gergely - Takács Péter (2012): A jövedelmi egyenlőtlenségek változásai és a szegénység In.: Fábián Gergely, Kiss János, Patyán László és Huszti Éva (szerk.): Életminőség Nyíregyházán 2008-2010 Acta Medicinae et Sociologica tematikus különszáma. Nyíregyháza: Debreceni Egyetem Orvos - és Egészségtudományi Centrum Egészségügyi Kar 33-49.

7. Ferge Zsuzsa (1995): A magyar segélyezési rendszer reformja. I. Esély, 6. sz. 43-63. 
8. Ferge Zsuzsa (1996a): A magyar segélyezési rendszer reformja. II. Esély, 1. sz. $25-43$.

9. Ferge Zsuzsa (1996b): A magyar segélyezés i rendszer reformja. III. Esély, 2. sz. 3-37.

10. Ferge Zsuzsa (1998): Szociális törvénykezés a rendszerváltás óta. Esély, 3. sz. 3-24.

11. Ferge Zsuzsa (2000): Elszabaduló egyenlőtlenségek Budapest: Hilscher Rezső Szociálpolitikai Egyesület, ELTE Szociális Intézet.

12. Filepné Nagy Éva - Fónai Mihály - Fábián Gergely (2006): A Szabolcs Szatmár - Bereg megyei népesség szociális helyzete és egészségi állapota. In: Fónai M - Pénzes M - Vitál A (szerk.): Etnikai szegénység, etnikai egészségi állapot? A cigány népesség élethelyzete és kitörési lehetőségei Északkelet-Magyarországon. Nyíregyháza: Krúdy Könyvkiadó - Szocio East Egyesület, 43-75.

13. Fónai Mihály (2011): A települési problémák és a lakossági szükségletek lehetséges hatása a helyi politikára. In.: Bódi Ferenc - Fábián Gergely (szerk.), Helyi szociális ellátórendszer Magyarországon. Debrecen: Debreceni Egyetemi Kiadó 73-95.

14. Gyulavári Tamás - Krémer Balázs (2006): Miért áttekinthetetlen a pénzbeli szociális ellátások rendszere? Esély 2. sz. 29-48.

15. Huszti Éva (2012): Társas kapcsolatok. Családi, rokoni, baráti kapcsolatok Nyíregyháza lakói körében 2008-2010. In.: Fábián Gergely, Kiss János, Patyán László és Huszti Éva (szerk.): Életminőség Nyíregyházán 20082010 Acta Medicinae et Sociologica tematikus különszáma. Nyíregyháza: Debreceni Egyetem Orvos - és Egészségtudományi Centrum Egészségügyi Kar 155-177.

16. Jövedelempótló támogatások az önkormányzati segélyezésben, 2000-2011, $\mathrm{KSH}$ (2013).

http://www.ksh.hu/docs/hun/xftp/idoszaki/pdf/jovedelempotlosegely.pdf

17. Krémer Balázs (2009): Bevezetés a szociálpolitikába. Budapest: Napvilág Kiadó.

18. Kuivalainen, Susan (2005): Families at the Margins of the Welfare State: A Comparative Study on the Prevalence of Poverty among Families Receiving Social Assistance. Luxembourg Income Study Working Paper Series.

Working Paper No. 403. February. www.lisproject.org/publications/liswps/403.pdf

19. Mózer (szerk.) (2004): Szükség van a változásra! Pénzbeli ellátások rendszere Írták: Darvas Ágnes, Győri Péter, König Éva, Mózer Péter és Tóth Zoltán Készült a SZOLID Projekt megbízásából, Budapest. 
20. Mózer Péter (2006): A szolgáltatásokhoz való hozzáférés (A jogosultsági szabályok újraértékelése). http://bmszki.hu/file/tekozlo/mozer/hozzaferes_szolg.hoz4.doc (1-18.)

21. Mózer Péter (2011): Szociálpolitika jövő időben Esély 6. sz. 3-34.

22. Neubourg, Chris de-Castonguay, Julie-Roelen, Keetie (2007): Social Safety Nets and targeted Social Assistance: Lessons from the European Experience. SP (Social Protection \& Labor) Discussion paper No. 0718. The World Bank, November.

23. http://siteresources.worldbank.org/SOCIALPROTECTION/Resources/SPDiscussion-papers/Safety-Nets-DP/0718.pdf

24. R. Fedor Anita (2012): A Gazdasági aktivitás lokális jellemzői. Nők és férfiak a „munka piacán” In: Fábián Gergely -Patyán László - Huszti Éva(szerk.): Életminőség Nyíregyházán 2008-2010 Acta Medicinae et Sociologica tematikus különszáma. Nyíregyháza: Debreceni Egyetem Orvos - és Egészségtudományi Centrum Egészségügyi Kar 83-99.

25. Szuhay Péter (1999): A magyarországi cigányság kultúrája: etnikus kultúra vagy a szegénység kultúrája? Budapest: Panoráma Kiadó.

26. Tausz Katalin (2010): Segélyezés Magyarországon In.: „A szociális segélyezés szerepe a segélyezettek életminőségének alakulásában" Tanulmánykötet. A TÁMOP 2.5.2 kódszámú kiemelt projekt keretében „A szociális segélyezés szerepe a segélyezettek életminőségének alakulásában” címü projekt keretén belül készült, a Foglalkozatási és Szociális Hivatal részére. Budapest 32-65.

\section{Felhasznált statisztikai kiadványok}

1. A foglalkoztatás és a munkanélküliség regionális különbségei, 2012. KSH. 2013. július http://www.ksh.hu/docs/hun/xftp/idoszaki/regiok/debrecenfoglmunk12.pdf

2. Társadalmi helyzetkép - 10. fejezet Szociális védelem 2010, KSH. www.ksh.hu/docs/hun/xftp/idoszaki/thk/thk10_szocialis.pdf

\section{Felhasznált joganyag}

1993. évi III. törvény a szociális igazgatásról és ellátásokról. 


\section{Felhasznált adatbázisok}

1. Eurostat, Social protection statistics, 2013.

http://epp.eurostat.ec.europa.eu/statistics_explained/index.php/Social_prote ction_statistics

2. KSH adatbázis.

http://statinfo.ksh.hu/Statinfo/haViewer.jsp

Balogh Erzsébet: tanársegéd

Debreceni Egyetem Egészségügyi Kar, 4400 Nyíregyháza, Sóstói u. 2-4.

R. Fedor Anita: föiskolai adjunktus

Debreceni Egyetem Egészségügyi Kar, 4400 Nyíregyháza, Sóstói u. 2-4. 